\title{
The prophylactic effect of Viscum album in streptozotocin-induced diabetic rats
}

\author{
Asuman Turkkan, ${ }^{1}$ Hasan Basri Savas, ${ }^{2}$ Berire Yavuz, ${ }^{1}$ \\ Ayse Yigit, ${ }^{3}$ Efkan Uz, ${ }^{3}$ Nezire Asli Bayram, ${ }^{4}$ Banu Kale ${ }^{5}$ \\ ${ }^{1}$ Suleyman Demirel University Faculty of Medicine, Isparta, Turkey \\ 2Department of Medical Biochemistry, Suleyman Demirel University Faculty of Medicine, Isparta, Turkey \\ ${ }^{3}$ Department of Medical Genetic, Suleyman Demirel University Faculty of Medicine, Isparta, Turkey \\ ${ }^{4}$ Department of Medical Biology and Genetic, Suleyman Demirel University Faculty of Medicine, Isparta, Turkey \\ ${ }^{5}$ Department of Internal Medicine, Suleyman Demirel University Faculty of Medicine, Isparta, Turkey
}

\section{ABSTRACT}

OBJECTIVE: Viscum album (VA) is a species of mistletoe in the family Santalaceae that is thought to have therapeutic properties for several diseases, including diabetes. In the present study, conventional experimental rat model was used with diabetes induced with streptozotocin (STZ) to evaluate effect of VA on lipid peroxidation and antioxidant system.

METHODS: Total of 32 adult, male Sprague-Dawley rats were divided into 4 groups of 8 rats: Control group, STZ group, VA group, and group administered VA+STZ. VA extract was $100 \mathrm{mg} / \mathrm{kg}$ preparation delivered once a day by oral gavage for 10 days. Single dose of $55 \mathrm{mg} / \mathrm{kg} \mathrm{STZ}$ citrate buffer $(0.1 \mathrm{M}, \mathrm{pH} 4.5)$ was administered intraperitoneally to induce diabetes. Fasting blood glucose level was measured and recorded. Animals were sacrificed, and catalase (CAT), malondialdehyde (MDA), and protein present in liver and kidney tissue samples were measured. Activity of CAT, an antioxidant enzyme, was studied according to the Aebi method. MDA, a product of lipid peroxidation, was analyzed using Draper and Hadley spectrophotometric procedure. Protein level was determined using supernatant and extract of tissue homogenates according to Lowry method. Data were assessed using one-way analysis of variance and pairwise comparisons between groups. Post-hoc analysis included Dunnet test, Duncan test, and least significant difference test. $\mathrm{P}<0.05$ was considered significant probability value.

RESULTS: Oxidative stress is associated with diabetic complications. VA administered to diabetic rats reduced oxidative stress and improved their general condition.

CONCLUSION: Further studies are needed to enhance understanding of potential antidiabetic and antioxidant effects of VA.

Keywords: Antioxidant; CAT; diabetes; MDA; Viscum album.

Received: December 01, 2015 Accepted: June 27, 2016

Correspondence: Dr. Hasan Basri SAVAS. Suleyman Demirel Universitesi Tip Fakultesi, Tibbi Biyokimya Anabilim Dalı 32200 Isparta, Turkey.

Tel: +90 246 - 2119406 e-mail: drhbs63@gmail.com

(c) Copyright 2016 by Istanbul Northern Anatolian Association of Public Hospitals - Available online at www.kuzeyklinikleri.com 
$V$ iscum album (mistletoe) is a plant growing in tropical and temperate climatic zones that contains alkaloids (substances which prevents parasitic infection in plants); lectins (proteins which can reversibly bind to carbohydrate residues on proteins); viscotoxins (substances with cytotoxic effects); polyholosides (substances which are effective against cancer and prevents the development of tumors); flavonoids (substances which are antioxidants, have protecting effects against cancer, and boost the immune system) $[1,2,3]$. While Viscum album causes economic damage by means of the increment and quality losses in trees on one hand, it produces benefits for human beings as a medicinal plant and for animal farming as a fodder plant on the other hand [4].

Diabetes is a condition developing because of the deterioration of the carbohydrate, fat and protein metabolisms resulting from the lack of the insulin secretion or decreased sensitivity of tissues to insulin. The deterioration in the antioxidant system also have a part in the decline in the clinic state of the patient. In diabetics, the fasting blood glucose, the plasma LDL (Low-Density Lipoprotein) and the free fatty acid levels increase remarkably [5].

In many studies conducted on Viscum album, antioxidant parameters have been examined and it has been found out that the plant might have an effect of decreasing the oxidative stress. A number of plant extracts, including that of Viscum album, have been applied on the groups comprising the stomach and colon tissues of cancer patients and healthy individuals, and it has been shown that Viscum album has an inhibiting effect on xanthine oxidase and adenosine deaminase, which shows an antioxidant activity [6]. There are also studies which have shown that Viscum album might increase the insulin secretion and improve the glycemic control. One of these studies is the study in which rats in which diabetes had been induced by means of STZ were given Viscum album for short and long periods (for 4 hours and 3 weeks respectively), the antidiabetic and antilipidemic effects of it were examined. The results of this study showed that Viscum album had caused hypoglycemia in these rats [7]. In another study carried out on 20
Wistar rats, the rats were divided into groups and, following a 12-hour period of hunger, they were loaded, depending on their groups, with glycose and Viscum album extract under phenobarbital anesthesia. Then blood samples were taken from the rats with fifteen-minute intervals for a period of 3 hours in order to examine their glycose, insulin and glucagon levels. While the extract resulted in no changes in the glucose levels in healthy rats, it lowered the level of blood sugar in diabetic rats (35.3\%). It was found out that the insulin secretion had increased both in diabetic and healthy rats and it was shown that Viscum album could have antiglycemic and insulinotropic effects [8].

In another study carried out on rats in which diabetes had been induced by means of STZ and which had been divided into groups based on the amount of Viscum album given to them, it was shown that Viscum album could have antihyperlipidemic and antioxidant properties (by releasing MDA and GSH) [9]. In another study carried out at the cellular level, it was shown that the Viscum album extract applied to pancreatic B cells could induce the secretion of insulin and thus could be used as an antidiabetic substance [10]. In a study in which the effectiveness of the herbal treatments used for diabetes was investigated, the rats in which diabetes had been induced by means of STZ were given Viscum album for a period of 9 days and it was found out that the extract resulted in a decrease in polyphagia and polydipsia. However, no effect was observed on the plasma glycose and insulin values. This suggests that Viscum album can be used in decreasing the symptoms without having any effect on glycemic control [11].

In recent years, studies on alternative medicine and treatment for protection against and curing diabetes have gained remarkable intensity. Although Viscum album is commonly used in folk medicine for diabetes treatment both in elderly and young people, there is no study which has been conducted about its use for protection against this disease. By means of the present study, it is aimed to investigate of the prophylactic effects of Viscum album, which is believed in Turkey to have a curing effect on a number of diseases including diabetes and thus is 
used commonly, on the antioxidant system and the plasma glycose levels in rats.

\section{MATERIALS AND THE METHODS}

\section{Animals}

32 adult male Sprague-Dawley rats weighing 200$250 \mathrm{~g}$ were used for experimental procedures. The ambient temperature and relative humidity of the animal room were $21 \pm 1^{\circ} \mathrm{C}$ and $60 \pm 7 \%$, respectively. The room was illuminated with artificial light for $12 / 12$ hours dark/light. The animals were allowed free access to standard pelleted food and tap water. The study, which was conducted after the required permit is obtained from the Local Council of Ethics for Animal Experiments in Süleyman Demirel University, was conducted in the Experiment Animals and Medical Investigation Implementation and Research Center in Süleyman Demirel University.

\section{Experimental design}

32 adult male Sprague-Dawley rats were divided into the following four groups, each containing eight rats: Control (C) group, streptozotocin (STZ) group, Viscum album (VA) group and Viscum album + streptozotocin (VA+STZ) group. After the STZ had been prepared in citrated buffer $(0.1 \mathrm{M}$, $\mathrm{pH} 4.5)$ with a rate of $55 \mathrm{mg} / \mathrm{kg}$, it was applied to rats in a single dose and in an intraperitoneal way [12]. Depending on their groups, the prepared extract was given to the rats daily by means of gavage for a period of 10 days $(100 \mathrm{mg} / \mathrm{kg})$. On the $11^{\text {th }}$ day, diabetes was induced by means of streptozotoin $(55 \mathrm{mg} / \mathrm{kg})$ in specified groups. The values were measured by means of the blood taken from their tails to glucometer strips.

\section{Preparation of Viscum album}

First, the leaves of the Viscum album collected from the Pınargözü region of the Elmaliyurt Village in the district of Gölhisar in the province of Burdur on January and February were separated and were dried in $45^{\circ} \mathrm{C}$ temperature for a period of 5-6 hours by the researcers. Then they were processed into small pieces in a blender to prepare the extract. The dry and ground leaves were mixed with the $95 \%$ ethanol at a rate of 1:5. Then the mixture was kept at $4^{\circ} \mathrm{C}$ for a period of 24 hours before sieving it using a $0.45 \mu \mathrm{m}$ membrane filter. After ethanol is removed from the solution, it was kept at $-20^{\circ} \mathrm{C}$ until it is used. The Viscum album extract was given to the rats in the relevant groups (to the groups 'VA' and 'VA+STZ') by means of oral gavage at a dose of $100 \mathrm{mg} / \mathrm{kg}$ for a period of 10 days.

\section{Inducing diabetes by using STZ}

After the STZ had been prepared in citrated buffer $(0.1 \mathrm{M}, \mathrm{pH} 4.5)$ with a rate of $55 \mathrm{mg} / \mathrm{kg}$, it was applied to rats in a single dose and in an intraperitoneal way [12]. The plasma glucose levels were determined by measuring them by glucometer using a drop of blood taken from the tip of the tails of the rats. Accutrend Plus GCT Glucometer was used for measuring of the plasma glucose levels of rats. The monitor of the glucometer device uses a reflectance photometer for measuring the intensity of the color formed at the end of the reaction. These measuring uses the software translates the intensity to the corresponding glucose values. Glucose is converted to gluconolactone with pyrolinquinol quinone-dependent GDH enzyme. This in turn reduced the enzyme forms. bis- next mediator in oxidized form enzyme returning to step (2-hydroxyethyl) - (4-hidroksiiminohekzo from 2,5-dienyl) ammonium chloride selectively reduces. The reduced mediators oxide and convert the yellow indicator to blue [13].

It was assumed that the disease had developed if the blood glycose level exceeds $250 \mathrm{mg} / \mathrm{dl}$. After the STZ had been applied, the blood glycose levels were monitored on a daily basis. At the end of the two weeks, the rats were sacrificed, their liver and kidney tissues were removed and their antioxidant parameters were examined.

\section{Biochemical measurements}

$0.05 \mathrm{M}$ Tris- $\mathrm{HCl}$ buffer with a $\mathrm{pH}$ value of 7.4 was used in the homogenization of the tissues. The tissue samples were weighed out by using a sensitive balance and their wet weights were recorded. Then they were placed in Eppendorf tubes and kept at 
TABLE 1. MDA-CAT and serum glucose levels in groups (mean \pm SEM)

\begin{tabular}{lccccc} 
& Liver MDA & Liver CAT & Kidney MDA & Kidney CAT & Glucose after STZ \\
\hline C & $0.16 \pm 0.020$ & $2.29 \pm 0.08$ & $0.23+0.01$ & $0.75 \pm 0.04$ & $165.50 \pm 15.09$ \\
STZ & $0.18 \pm 0.018$ & $1.60 \pm 0.14$ & $0.28 \pm 0.01$ & $0.55 \pm 0.04$ & $442.25 \pm 17.47$ \\
VA & $0.22 \pm 0.05$ & $2.36 \pm 0.22$ & $0.28 \pm 0.02$ & $0.70 \pm 0.04$ & $255.50 \pm 12.93$ \\
VA+STZ & $0.26 \pm 0.02$ & $2.02 \pm 0.11$ & $0.28 \pm 0.01$ & $0.79 \pm 0.06$ & $392.00 \pm 14.24$ \\
\hline
\end{tabular}

C: Control group; STZ: Streptozotocin group; VA: Viscum album group and Viscum album+streptozotocin (VA+STZ) group; SEM: standard error mean.

$-80^{\circ} \mathrm{C}$ until the biochemical examinations are conducted on them.

At the beginning of the homogenization process, the wet weights of the tissues were determined. They were put into glass tubes by maintaining their low temperature and then $2 \mathrm{ml}$ of cold Tris- $\mathrm{HCl}$ buffer was added over them. Then plastic bowls were filled with ice and the tissues in glass tubes were placed in these plastic bowls and they were homogenized at $16.000 \mathrm{rev} / \mathrm{min}$ for a period of 3 minutes. Buffer was added in a way that the last volume was 10 times the weight of the weight of the tissue. By maintaining them in low temperature, the homogenates were placed into the Eppendorf tubes. The amount of MDA protein was determined by using the homogenates obtained. By means of the centrifugation of the homogenates at $+4^{\circ} \mathrm{C}$ at $5.000 \mathrm{rev}$ (min for a period of 30 minutes, supernatants were obtained. Then, from the selected supernatants, the amount of proteins was determined by means of CAT enzyme activities. The tissue homogenates, supernatants and extracts were backed up and kept at $-80^{\circ} \mathrm{C}[14]$.

\section{Determining the proteins}

Determination of the proteins in the homogenates, supernatants and extracts of the homogenized samples was carried out by using the Lowry method. According to this method, the cupper-protein complex is formed in the alkali solution, which, in turn, reduces the Folin-Ciocalteu-Phenol reagent, resulting in a dark blue color. The degree of the darkness of the blue color is directly proportional with the concentration of the protein.

\section{Determining the MDA}

MDA is a product of lipid peroxidation. The amount of malondialdehyde was determined by the spectrophotometric method based on the Draper and Hadley's method. In this method, the color produced by the reaction of MDA and thiobarbituric acid (TBA) is considered by means of a spectrophotometric measurement [15].

\section{Determining the CAT activity}

Catalase activity was examined using the Aebi's method. Hydrogen peroxide $\left(\mathrm{H}_{2} \mathrm{O}_{2}\right)$ gives maximum absorbance at $240 \mathrm{~nm}$. The $\mathrm{H}_{2} \mathrm{O}_{2}$ added into the experimental environment is broken down by the catalase enzyme into water and oxygen, which manifests itself on the ultraviolet spectrum as a decrease in the absorbance. This decrease in the absorbance is directly proportional to the activity of the CAT enzyme [16].

\section{Statistical analysis}

SPSS 20.00 package program was used for statistical analysis. ANOVA which is a parametric test, was performed for comparing of groups MDA and CAT levels. 0.05 was considered significant. In the significant parameters, post hoc Dunnet, Duncan, LSD tests were performed. Numerical data obtained were expressed as mean \pm standard error (SEM).

\section{RESULTS}

When the liver MDA values are compared between STZ and VA groups and between STZ and C 
groups, it was seen that the MDA values are lower in the STZ group ( $p=0.006$ and 0.015 , respectively). The differences between the liver MDA values of the other groups were found to be insignificant.

The comparison of the kidney MDA values between the STZ and C groups, STZ and VA groups, and STZ and VA+STZ groups showed that the MDA level was significantly higher in the STZ group ( $p=0.029, p=0.014$ and $p=0.011$, respectively).

When the kidney CAT activity is compared between the STZ and C groups and the STZ and $\mathrm{STZ}+\mathrm{VA}$ groups, it was found to be lower in the STZ group ( $p=0.028$ and $p=0.006)$.

When the liver CAT values are compared between the STZ and C groups and the STZ and VA groups, a significant decrease was observed in the STZ group ( $\mathrm{p}=0.012$ and $\mathrm{p}=0.006)$.

When the glucose values following the application of STZ were examined, it was seen that the glucose value for the VA group was higher than that for the $C$ group $(p=0.001)$; the glucose value for the STZ group was significantly higher than that for the $C$ group $(p=0.000)$; and the glucose value for the STZ+VA group was higher than that for the C group $(p=0.000)$. When the glucose values for the VA and STZ groups were compared, it was seen that the glucose value for the STZ group was higher $(p=0.000)$; and, when the values for the VA and STZ+VA groups were compared, the glucose value for STZ+VA was found to be higher $(p=0.000)$. No significant difference was found out between the STZ+VA and STZ groups in terms of their glucose levels.

\section{DISCUSSION}

When the balance between the free radicals produced during the physiological processes occurring in the body or during pathological processes and the antioxidant system is disturbed in favor of the free radicals, the oxidative damage occurs. The organism tries to protect itself against this oxidative damage by enzymatic and non-enzymatic ways. Catalase and MDA are among the important enzymes used in this enzymatic process of protection.
Diabetes is a disease that affects the millions of people every sex and race effective and globally every year $[17,18]$. Diabetes is a disease which disturbs the glycemic control and the antioxidant metabolism disorder plays a role in the development of the clinic state. In a study investigating the possible effects of Viscum album, in decreasing oxidative stress, which have been applied on the stomach and colon tissues of cancer patients and healthy individuals, it has been shown that Viscum album has an inhibiting effect on xanthine oxidase and adenosine deaminase [6]. There is also a study which have shown that Viscum album might increase the insulin secretion and improve the glycemic control. In this study, rats in which diabetes had been induced by means of STZ were given Viscum album for short and long periods (for 4 hours and 3 weeks respectively) and the antidiabetic and antilipidemic effects of it were examined. The results of this study showed that Viscum album had caused hypoglycemia in these rats [7]. In another study carried out on Wistar rats, the rats were divided into groups and, following a 12-hour period of hunger, they were loaded, depending on their groups, with glucose and Viscum album extract. Then blood samples were taken from the rats in order to examine their glycose, insulin and glucagon levels. While the extract resulted in no changes in the glucose levels in healthy rats, it lowered the level of blood sugar in diabetic rats. It was found out that the insulin secretion had increased both in diabetic and healthy rats and it was shown that Viscum album could have antiglycemic and insulinotropic effects [8]. In a study carried out on rats in which diabetes had been induced by means of STZ and which had been divided into groups based on the amount of Viscum album given to them, it was shown that Viscum album could have antihyperlipidemic and antioxidant properties (by releasing MDA and GSH) [9]. In another study carried out at the cellular level, it was shown that the Viscum album extract applied to pancreatic B cells could induce the secretion of insulin and thus could be used as an antidiabetic substance [10]. In a study in which the effectiveness of the herbal treatments used for diabetes was investigated, the rats in which diabetes had been induced by means of 
STZ were given Viscum album and it was found out that the extract resulted in a decrease in polyphagia and polydipsia. However, no effect was observed on the plasma glycose and insulin values. This suggests that Viscum album can be used in decreasing the symptoms without having any effect on glycemic control [11].

In the present study, which has been conducted at the biochemical level, the antioxidant activity in the liver and kidney tissues of rats has been investigated. This activity has been tried to be calculated based on the levels of MDA, which plays an important role in lipid peroxidation and has a function of decreasing the oxidative stress, and catalase, which is an antioxidant enzyme. When the MDA values are compared among the groups formed within the scope of the experiment, significant differences were found out between the STZ and VA groups $(p=0.014)$ and STZ and VA+STZ groups $(p=0.011)$, the values being higher for the STZ group. In the rats in which diabetes had been induced, the Viscum album given beforehand resulted in significant changes in the kidney MDA values, which has an effect of decreasing the oxidative stress. When the blood sugar values were analyzed after the application of the STZ, no significant difference was found out between the STZ+VA and STZ groups. This indicates that the Viscum album given beforehand has no effect on the glycemic control.

Consequently, an increase in the enzymatic activity of catalase, which is an antioxidant enzyme functioning in the kidney tissue, and a decrease in the level of MDA, which is an indication of lipid peroxidation, were observed among the rats given Viscum album. Considering the fact that a decrease in the oxidative stress provides positive contributions for the improvement of the clinical state and the overall situation in diabetes, it can be said that Viscum album can produce benefits in the improvement of the clinical state in diabetics. However, there is a need for further studies, especially the studies investigating the active ingredient, in order to find out the degree of the antioxidant and antidiabetic effects of $\mathrm{Vis}$ cum album.
Conflict of Interest: None declared.

Financial Disclosure: The authors declared that this study has received no financial support.

\section{REFERENCES}

1. Baytop T. Türkiyéde bitkiler ile tedavi (Geçmişte ve Bugün). İ.Ü. Yay. No: 3560, Ecz. Fak. Yay. No: 54, İstanbul (1984).

2. Miller AG. Viscum album L. (Flora of Turkey and the East Aegean Islands) vol. 7, Davis, P.H. University Press, Edinburgh (1982).

3. Zeybek N. Farmasötik Botanik, Kapalı Tohumlu Bitkiler (Angiospermae) Sistematiği ve Önemli Maddeleri, Ege Üniv. Ecz. Fak., No:1, Ege Üniv. Basımevi, İzmir (1985).

4. Yüksel B, Akbulut S, Keten A. Çam Ökseotu (Viscum album ssp. austriacum (wiesb.) vollman)'nun Zararı, Biyolojisi ve Mücadelesi. Süleyman Demirel Üniversitesi Orman Fakültesi Dergisi 2005;2:111-24.

5. Thomas E. Andreoli. Cecil Essential of Medicine. 4th ed. 1997. (Claude BJ, Charles CJ, Fred P, Russell CL. Cecil Essentials of Medicine. 4th ed. 1997).

6. Namuslu M, Kocaoglu H, Celik HT, Avci A, Devrim E, Genc $Y$, et al. Effects of aqueous soybean, mistletoe and red clover extracts on activities of adenosine deaminase and xanthine oxidase enzyme. Bratisl Lek Listy 2014;115:367-71. Crossref

7. Adaramoye O, Amanlou M, Habibi-Rezaei M, Pasalar P, Ali MM. Methanolic extract of African mistletoe (Viscum album) improves carbohydrate metabolism and hyperlipidemia in streptozotocin-induced diabetic rats. Asian Pac J Trop Med 2012;5:427-33. Crossref

8. Eno AE, Ofem OE, Nku CO, Ani EJ, Itam EH. Stimulation of insulin secretion by Viscum album (mistletoe) leaf extract in streptozotocin-induced diabetic rats. Afr J Med Med Sci 2008;37:141-7.

9. Orhan DD, Aslan M, Sendogdu N, Ergun F, Yesilada E. Evaluation of the hypoglycemic effect and antioxidant activity of three Viscum album subspecies (European mistletoe) in streptozotocin-diabetic rats. J Ethnopharmacol 2005;98:95-102. Crossref

10. Gray AM, Flatt PR. Insulin-secreting activity of the traditional antidiabetic plant Viscum album (mistletoe). J Endocrinol 1999;160:409-14. Crossref

11. Swanston-Flatt SK, Day C, Bailey CJ, Flatt PR. Evaluation of traditional plant treatments for diabetes: studies in streptozotocin diabetic mice. Acta Diabetol Lat 1989;26:51-5. Crossref

12. Ergun F, Deliorman D. Viscum album L. (Ökse Otu) Bitkisinin Kimyasal Bileşimi. Ankara Ecz Fak Der 1995;24:95-107.

13. Ekiz E, Duran ŞA, Ulaş M. Hastabaşı Sistemlerle Yapılan Glukoz Monitörizasyonunda Hangi Yöntem Daha Doğru? Türk Klinik Biyokimya Derg 2014;12:1-7.

14. Inui M, Kadoma M, Tada M. Purification and characterization 
of phospholamban from canine cardiac sarcoplasmic reticulum. J Biol Chem 1985;260:3708-15.

15. Draper HH, Hadley M. Malondialdehyde determination as index of lipid peroxidation. Methods Enzymol 1990;86:421-32.

16. Aebi H. Catalase In: Bergmeyer HU(ed) Methods of enzymatic analysis. New York and London Academic Press 1974;673-
7. Crossref

17. Lavin N. Lippincott Williams \& Wilkins, Endokrinoloji ve Metabolizma El Kitabı, 3. Baskı. İstanbul: Güneş Kitabevi 2006. s. 12-82.

18. Özenoğlu A, Hatemi HH. Diabette Beslenme. İstanbul: İstanbul Medikal Yayıncilık 2004. s. 12-8. 